\title{
FORMATION AND PROPERTIES OF POLYMER NANOLAYERS TO ENHANCE CELL GROWTH IN VITRO
}

\author{
O.V. Shtapenko1*, I.I. Hevkan1, Yu.I. Slyvchuk1, V.Y. Syrvatka², N.M. Matvienko \\ 1 Institute of Animal Biology, National Academy of Agrarian Sciences, Lviv, Ukraine \\ 2Ivan Franko National University of Lviv, Lviv, Ukraine \\ 3Institute of Fisheries, National Academy of Agrarian Sciences, Kyiv, Ukraine \\ *Corresponding author: shtapenko31@gmail.com \\ Received 29 March 2018; Accepted 23 June 2018
}

\begin{abstract}
Background. Cultivation of cell cultures on synthetic coating makes it possible to obtain a complex spatially organized cellular system that enhances cell attachment and determines all further processes of differentiation, proliferation, and formation of extracellular matrix. It is necessary to examine properties of coatings, particularly, such as biocompatible polymers with cells, as they can be applied for various biological and medical applications.

Objective. We investigated the effects of glass surfaces modified with dextran, APTES, albumin and they compositions on the proliferation and metabolic activity of B16F10 cells.

Methods. Cellular line B16F10 were cultured in DMEM medium supplemented with $10 \%$ fetal calf serum, $1 \%$ penicillin-streptomycin in $5 \% \mathrm{CO}_{2}$ at $37{ }^{\circ} \mathrm{C}$ for $72 \mathrm{~h}$. Cells were seeded at the glass plates, which modified nanolayers in various combinations: control group - glass, glass/APTES, glass/APTES/ dextran, glass/APTES/albumin, glass/albumin, glass/APTES/dextran/albumin. The influence of the surface properties on the proliferation of B16F10culture and its viability was analyzed after every $24 \mathrm{~h}$ of incubation. The cultural medium was collected after 24,48 , and $72 \mathrm{~h}$ of cultivation for investigation lactate dehydrogenase activity.

Results. The high viability and proliferation growth of cells on APTES, albumin, and APTES/dextran/ albumin coating were higher if compared with growth of cells on a glass surface. Improved the proliferation of the B16F10 cells was observed onto albumin $(P<0.001)$ and APTES/dextran/albumin $(P<0.001)$ nanolayers on 48 and $72 \mathrm{~h}$, in contrast to to control and other experimental groups. Whereas, the difference between the number of cells grown on glass and APTES coating increases only on $72 \mathrm{~h}$ of cultivation. Conclusions. Obtained results have shown that the glass surface modified albumin and APTES/dextran/ albumin resulted in improving the viability and cell proliferation of B16F10cell line and can be used as a 3D system for cultivation of cells of different types.
\end{abstract}

Keywords: cell culture; proliferative activity; surface; nanolayers.

\section{Introduction}

Three-dimensional (3D) cultures models may more accurate representation of the in vivo environment than two-dimensional (2D) cultures while maintaining the cytoarchitecture of in situ tissue that supports cells differentiation or maturation $[1,2]$.

Cell adhesion is depended upon surface hydrophilicity, surface charge density, surface morphology, specific chemical groups present on the surface of the scaffold [3]. Given that surface chemistry is crucial for the biocompatibility of the nanolayers, specific surface modifications are used with different polymers [4, 5].

In particular, there is an increased interest in the polymeric surfaces which can change their affinity towards proteins and cells under external stimuli $[6,7]$ and therefore have potential applications in biology and medicine.
Despite various investigations, specific and complex mechanisms govern the reactions that occur between the biomaterial and the cellular environment are still incomplete understanding.

The objective of this study was to establish and comparison cells line B16F10 viability cultured onto different coatings. We used surfaces obtained by grafting APTES, dextran, albumin and their combinations to the surface of the modified glass plates.

\section{Materials and Methods}

Preparation of coatings. Glass plates $(20 \times 20)$ were dipped into $0.2 \%(\mathrm{w} / \mathrm{w})$ methanolic solution of (3-aminopropyl)triethoxysilane (APTES) for $24 \mathrm{~h}$. After the incubation, loosely-attached silane molecules were removed with methanol in Soxhlet's apparatus. Then the plates functionalized with APTES 
were dipped into $1 \%$ solution of peroxide in air dioxin for $24 \mathrm{~h}$. Similarly, loosely attached peroxide was removed with dioxane in Soxhlet's apparatus for $4 \mathrm{~h}$. As a result, peroxides grafted to aminated surfaces were obtained [8].

With participation of these aminogroups dialdehydedextran obtained by partial oxidation of the anhydroglucopyranoside subunits of dextran by periodate acid was covalently grafted to the surface of the modified glass plates. The oxidation of dextran was conducted for $2 \mathrm{~h}$, and then the plates functionalized with amino-terminated APTES were dipped into $2 \%$ solution of dialdehydedextran in water for a grafting time of $6 \mathrm{~h}$. Similarly, loosely-attached dialdehydedextran was removed with water in Soxhlet's apparatus for $4 \mathrm{~h}$. As a result, dialdehydedextran grafted to aminated surfaces were obtained.

After modification procedure, all groups of samples were dipped in bovine serum albumin (BSA) phosphate-citric buffer solution $(\mathrm{pH} 7.4$; BSA $-0.2 \mathrm{mg} / \mathrm{ml}$ and adsorption time $-2 \mathrm{~h}$ ). Obtained surfaces were characterized by E. Bittrich [9].

Cell assay. B16 Melanoma Cells (B16-F10 cell ATCC \#CRL-6475) were harvested and cultivated in DMEM medium supplemented with $10 \%$ fetal calf serum (FBS, Gibco, USA), penicillin $(100 \mathrm{U} / \mathrm{ml})$ and streptomycin $(100 \mu \mathrm{g} / \mathrm{ml})$ (Gibco, USA) for $72 \mathrm{~h}$ at $37^{\circ} \mathrm{C}$ in an atmosphere containing $5 \% \mathrm{CO}_{2}$ and maximum humidity. Cells were seeded with an initial concentration of 800 thousands cells in a 100 $\mu l$ drop of the medium on glass (control) and coating modified with Glass/APTES; Glass/APTES/ dextran; Glass/APTES/albumin; Glass/albumin; Glass/APTES/dextran/albumin.

The influence of the surface properties on the proliferation of B16-F10 cells culture and its ability to form a monolayer was investigated. Cells were allowed to attach and proliferate for 24, 48, and $72 \mathrm{~h}$. After each time point, the number of plated cells was determined by counting using a hematocytometer. For each group, three samples were tested independently. Trypan blue exclusion test $(0.4 \%)$ was used to discriminate and count living cells.
Lactate dehydrogenase (LDH) assays. Medium supernatants collected from both experimental and control cells every $24 \mathrm{~h}$ were tested for LDH activity using Cytotoxicity Detection kit LDH (Roche). This test is a colorimetric assay for the quantification of cell death and cell lysis based on the measurement of LDH activity released from the cytosol of damaged cells into the supernatant. The amount of enzyme activity detected in the culture supernatant correlates with the proportion of lysed cells. The assays were conducted following the manufacturer's instructions, in flat-bottomed wells of 96well plates. Following incubation, the absorbance of samples was measured at a wavelength of $490 \mathrm{~nm}$ as a measure of enzyme activity using an ELISA (enzyme-linked immunosorbent assay) plate reader.

Evaluation of cytotoxicity using the microtetrazolium (MTT) assay. The MTT assay was used to assess the in vitro cytotoxicity of surface-modified glasses in this study. A quantitative colorimetric MTT test was performed after 3 days of culture to characterize cellular metabolism (vitality) and, by implication, proliferation. The MTT solution $(0.5 \mathrm{mg} / \mathrm{ml})$ was added to each well $3 \mathrm{~h}$ prior to the end of the experiment. After the incubation period dimethylsulfoxide was added in the dish to dissolve the purple formazan crystals that formed as a result of the restoration of MTT reagent-reductase living cells. The concentration of formazan in the wells was determined by the spectrophotometric method at a wavelength of $490 \mathrm{~nm}$. The number of living cells (in percentage) was determined by the ratio of optical in which the cells were incubated for study and control mediums.

Statistical analysis. Tests were repeated three times for every type of the samples. The results were presented as the mean \pm standard deviation. Differences between groups were determined by Student t-tests.

\section{Results}

The influence of the surface nature on the proliferative growth of B16F10 cells during $72 \mathrm{~h}$ was investigated (Table).

Table: Proliferative growth of B16F10 cells onto the modified surfaces during $72 \mathrm{~h}$ cultivation $(M \pm m, n=3)$

\begin{tabular}{|l|c|c|c|}
\hline \multirow{2}{*}{\multicolumn{1}{|c|}{ Experimental groups }} & \multicolumn{3}{c|}{ Number of cells $\left(\times 10^{6}\right)$} \\
\cline { 2 - 4 } & $24 \mathrm{~h}$ & $48 \mathrm{~h}$ & $72 \mathrm{~h}$ \\
\hline Control (glass) & $2.03 \pm 0.02$ & $2.33 \pm 0.05$ & $2.50 \pm 0.03$ \\
\hline Glass/APTES & $1.65 \pm 0.03^{* * *}$ & $2.19 \pm 0.03$ & $2.99 \pm 0.08^{* *}$ \\
\hline Glass/APTES/dextran & $1.80 \pm 0.06^{* *}$ & $2.13 \pm 0.04^{*}$ & $2.23 \pm 0.05^{* *}$ \\
\hline Glass/APTES/albumin & $2.81 \pm 0.04^{* * *}$ & $2.58 \pm 0.04^{* * *}$ & $2.61 \pm 0.02$ \\
\hline Glass/albumin & $1.37 \pm 0.07^{* * *}$ & $3.13 \pm 0.06^{* * *}$ & $3.14 \pm 0.07^{* * *}$ \\
\hline Glass/APTES/dextran/albumin & $1.94 \pm 0.03$ & $2.71 \pm 0.04^{* *}$ & $3.13 \pm 0.04^{* * *}$ \\
\hline
\end{tabular}

* $P<0.05$; ** $P<0.01$; *** $P<0.001$ compared to the control. 
The results of our investigations show that proliferative activity of B16F10 cells was gradually increased in the experimental group with APTES $(P<0.01)$. While in the experimental groups with APTES/dextran cells concentration were lower compared to control. Improved the viability and proliferation of the B16F10 cells were observed after cultivation onto albumin $(P<0.001)$ and APTES/dextran/albumin $(P<0.001)$ nanolayers during 48 and $72 \mathrm{~h}$ compared to control and other experimental groups.

The viability and functional activity of B16F10 cells under cultivation onto different nanolayers we investigated of LDH levels (Fig. 1).

LDH concentration in all groups was sufficiently high at the beginning of the experiment. As increasing times cultivation, LDH activity was

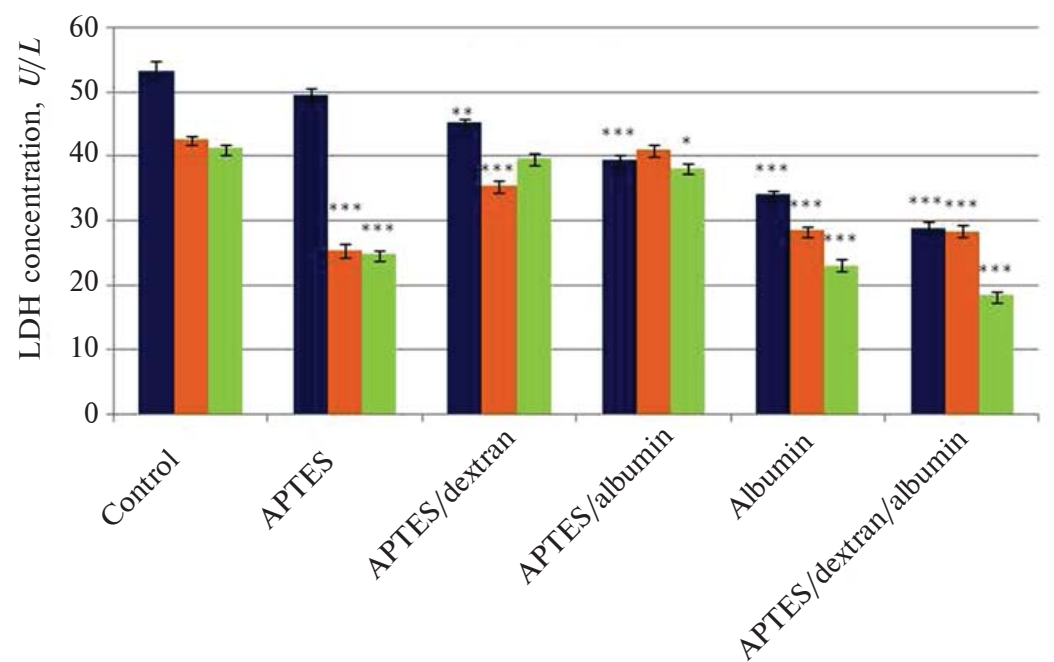

Figure 1: LDH activity in culture medium after cultivation B16F10 cells onto different nanolayers during $72 \mathrm{~h}(M \pm m, n=3)$. Results are expressed as mean of three independent experiments: $\square-24 \mathrm{~h}$; $-48 \mathrm{~h}$; $\square-72 \mathrm{~h}$. Note: ${ }^{*} P<$ $<0.05$; ** $P<0.01$; *** $P<0.001$ compared to the control

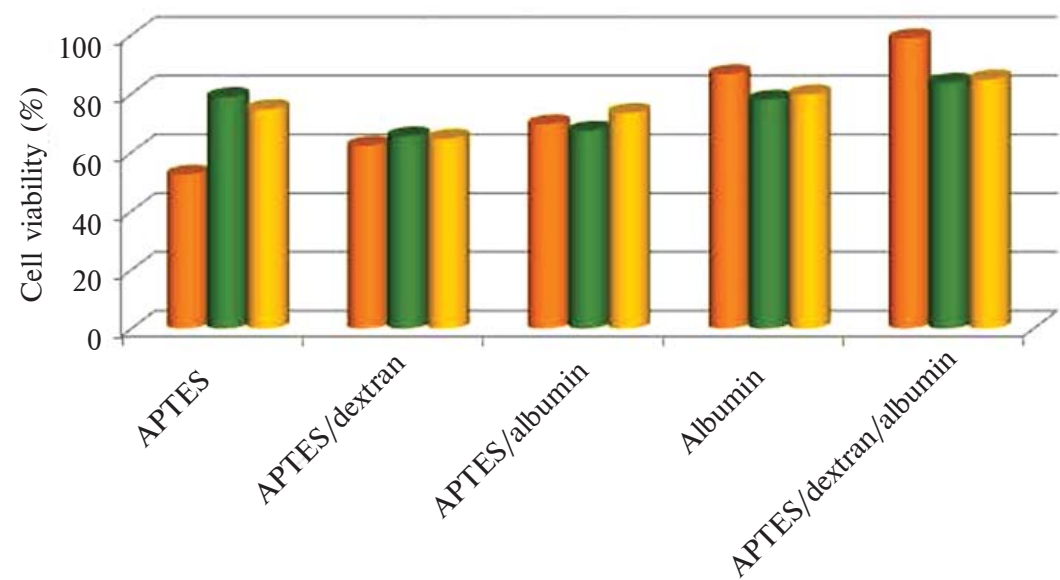

Figure 2: Viability of B16F10 cells exposed onto different nanolayers after $72 \mathrm{~h}$ incubation. The cytotoxicity was determined by MTT assay as the percentage of experimental cells compared with control: $-24 \mathrm{~h}$; $-48 \mathrm{~h}$; $\square-72 \mathrm{~h}$ changed differently in each group. Enzyme activity significantly reduced in cells cultivated onto APTES, albumin and APTES/dextran/albumin coating at 48 and $72 \mathrm{~h}$ as opposed to the group with APTES/dextran coating. The higher concentration of LDH during whole time cultivation were bserved in the experimental group with APTES/ Decreasing lactate dehydrogenase activity was albumin coating experimental groups at $48-72$ h of cultivation, which coincides with the growth of the proliferative activity of cells in these groups and high cell viability.

Biocompatibility and functional impact of modified surfaces were studied in vitro using MTT assay. In Fig. 2 the data of obtained results of MTT absorbance value for cells after cultivation onto different nanolayers are representing.

The cell viability in the experimental group with APTES/dextran/albumin was the highest during the whole time of cultivation compared to other experimental groups. Whereas the lowest cell viability was noted in the experimental group with APTES/dextran. The absorbance values in experimental groups with albumin and APTES/albumin were also higher. The MTT assay showed 86.6$79.7 \%$ and $69.5-73.4 \%$ of viability to $\mathrm{B} 16 \mathrm{~F} 10$ cells in this groups respectively.

\section{Discussion}

Most cells are anchorage-dependent because they grow as monolayers and require attachment to proliferate. Disposable plastic, especially polystyrene is now most commonly used for cell culture growth. But many cells prefer surfaces with high surface energies (i.e. hydrophilic surfaces). Whereas most plastics are hydrophobic and unsuitable for cell growth, they are often treated with radiation, chemicals or electric ion discharge to generate a charged, hydrophilic surface. The characteristics of glasses depend on organic compounds properties present in their composites its chemical composition, surface area, and textural properties (pore size, pore volume, pore structure) [10]. Given that surface chemistry is crucial for the biocom- 
patibility of the nanolayers, the coatings should be tested on various cell types [11]. But methods of investigations of effects of the biocompatible and smart bioactive surfaces on cells are still not fully developed. For these studies usually are applied cell viability tests and counted a quantity of the living cells with different morphology and also their proliferation index. Among different surface modification approaches studied, grafting of carbon nanotubes on the surface provides the growth, morphology and cell viability of bone cells (osteoblasts) [12]. This positive effect on cell viability may be attributed to the fact that nanotubes create $3 \mathrm{D}$ cultures models that can provide additional nucleation and growth sites for cells to thrive.

In our studies, the cell viability rate and proliferation were showed an increase after cultivation of B16-F10 cell on the surface with grafted nanolayers of APTES, albumin and APTES/dextran/albumin during $72 \mathrm{~h}$. While using coating glasses, a moderate cytotoxicity was observed after $72 \mathrm{~h}$ of incubation. The increased sensitivity of B16F10 cells (cell growth induction as well as inhibition) suggests that the effects may be dependent on nature of the polymer nanolayers. So it could be concluded that the stereochemistry of the polymers used for coating glasses greatly influence the cell growth and survival. This agrees with another study [13] and could be explained by the organization and maturation of the extracellular matrix surrounding cells by the created threedimensional system.
An additional approach for the detection of cells viability is the determination of LDH levels. $\mathrm{LDH}$ is a stable cytoplasmic enzyme present in all cells and is rapidly released following damage to the plasma membrane [14]. Evaluation of LDH activity is crucial in the study of cell viability. From with the increasing of cultivation time, LDH activity was changed differently for each group, but, in general, its concentration in the control group and in all experimental groups was similar, which indicates to proliferative activity of cells. These results confirm by the index of MTT value: the viability of B16F10 cells cultivated onto different nanolayers after $72 \mathrm{~h}$ incubation number remains at a high level.

\section{Conclusions}

The different coatings were created through grafting of APTES, dextran, albumin and their combinations on glass surfaces. The effect of those nanolayers was studied on B16-F10 cell line in terms of change cell viability and morphology during $72 \mathrm{~h}$ of incubation. These coatings present different morphologies according to the introduced polymer nanolayers. It was found out that modification of the surface with grafted nanolayers of APTES, albumin and APTES/dextran/albumin is allows improving the viability and proliferation of B16-F10 cell. These results confirm the advantage of nanolayers surface for applications in cell biology and medicine because they create three-dimensional (3D) system and ensures optimum for the cultivation of cells in vitro.

\section{References}

[1] Edmondson R, Broglie JJ, Adcock AF, Yang L. Three-dimensional cell culture systems and their applications in drug discovery and cell-based biosensors. Assay Drug Dev Technol. 2014;12(4):207-18. DOI: 10.1089/adt.2014.573

[2] Madich A, Sheremeta V, Hevkan I, Shtapenko O, Fedorova S, Slyvchuk Yu. Cell culture and its possible use in embryonic biotechnology. Kyiv: ArtEkom, 2012. 144 p.

[3] Ishizaki T, Saito N, Takai O. Correlation of cell adhesive behaviors on superhydrophobic, superhydrophilic, and micropatterned superhydrophobic/superhydrophilic surfaces totheir surface chemistry. Langmuir. 2010 Feb;26(11):8147-54. DOI: 10.1021/ la904447c

[4] Miksa D, Irish ER, Chen D, Composto RJ, Eckmann DM. Dextran functionalized surfaces via reductive amination: morphology, wetting, and adhesion. Biomacromolecules. 2005 Dec 27;7(2):557-64. DOI: 10.1021/bm050601o

[5] Rabe M, Verdes D, Seeger S. Surface-induced spreading phenomenon of protein clusters. Soft Matter. 2009 Aug;5:1039-47. DOI: $10.1039 / \mathrm{B} 814053 \mathrm{G}$

[6] Noorisafa F, Razmjou A, Emams N, Low Z-X, Korayem H, Kajani AA. Surface modification of polyurethane via creating a biocompatible superhydrophilic nanostructured layer: role of surface chemistry and structure. J Experimental Nanosci. 2016;11(14):1087-109. DOI: 10.1080/17458080.2016.1188223

[7] Brynda E, Houska M, Jirouskova M. Albumin and heparin multilayer coatings for blood-contacting medical devices. J Biomed Mater Res. 2000 May;51(2):249-57. DOI: 10.1002/(SICI) 1097-4636(200008)51:2<249::AID-JBM14>3.0.CO;2-X

[8] Luzinov I, Minko S, Tsukruk VV. Responsive brush layers: from tailored gradients to reversibly assembled nanoparticles. Soft Matter. 2008 Feb,4:714. DOI: 10.1039/B718999K

[9] Bittrich E, Burkert S, Müller M, Eichhorn KJ, Stamm M, Uhlman P. Temperature-sensitive swelling of poly(N-isopropylacrylamide) brushes with low molecular weight and grafting density. Langmuir. 2012 Feb;28(7):3439-48. DOI: 10.1021/la204230a 
[10] Kaur gurbinder clinical applications of biomaterials: state-of-the-art progress, trends, and novel approaches [Internet]. Springer; 2017 [cited 22 May 2018]. 467 p. Available from: https://www.springer.com/gb/book/9783319560588

[11] Wendy K, Scholz W. Cell adhesion and growth on coated or modified glass or plastic surfaces [Internet]. Tools.thermofisher. com. 2018 [cited 22 May 2018]. Available from: https://tools.thermofisher.com/content/sfs/brochures/D00253.pdf

[12] Maurer E, Hussain S, Mukhopadhyay SM. Cell growth in a porous microcellular structure: Influence of surface modification and nanostructures. Nanosci Nanotechnol Lett 2011;3(1):110-3. DOI: 10.1166/nnl.2011.1128

[13] Alves LB, de Souza SLS, Taba JM, Novaes ABJr, Oliveira PT, Palioto DB. Bioactive glass particles in two-dimensional and three-dimensional osteogenic cell cultures. Braz Dent J. 2017 May/June;28(3). DOI: 10.1590/0103-6440201600953

[14] Legrand C, Bour JM, Jacob C, Capiaumont J, Martial A, Marc A, et al. Lactate dehydrogenase (LDH) activity of the cultured eukaryotic cells as marker of the number of dead cells in the medium. J Biotechnol. 1992;25(3):231-43. DOI: 10.1016/01681656(92)90158-6

\section{О.В. Штапенко, І.І. Гевкан, Ю.І. Сливчук, В.Я. Сирватка, Н.М. Матвієнко}

\section{ФОРМУВАННЯ І ВЛАСТИВОСТІ ПОЛІМЕРНИХ НАНОШАРІВ ДЛЯ ПОЛІПШЕННЯ РОСТУ КЛІТИН IN VITRO}

Проблематика. Культивування культур клітин на синтетичних покриттях дає можливість отримати комплексну просторово організовану клітинну систему, що підвищує прикріплення клітин і сприяє їх подальшій диференціації, проліферації та фрормуванню міжклітинного матриксу. Тому виникає потреба у вивченні властивостей покриттів, зокрема біосумісності з клітинами, оскільки вони можуть бути використанні для різних біологічних і медичних досліджень.

Мета. Завданням наших досліджень є вивчення впливу наноповерхонь, модифікованих АПТЕСом, декстраном, альбуміном та їх композиціями, на проліферативну і метаболічну активність клітин B16F10.

Методика реалізації. У дослідженні використовували клітини лінії B16F10, які культивували на живильному середовищі ДМЕМ із додаванням 10 \% ЕTC, 1 \% пеніциліну та стрептоміцину в атмосфері з вмістом 5 \% СО 2 при $37{ }^{\circ} \mathrm{C}$ упродовж 72 год. Клітини висівали на скельця, модифіковані наношарами у різних комбінаціях: контрольна група - скло; скло/APTES; скло/APTES/декстран; скло/APTES/альбумін; скло/альбумін; скло/APTES/декстран/альбумін. Вплив покриттів на проліферативний ріст і життєздатність культури оцінювали кожні 24 год культивування. Для визначення активності лактатдегідрогенази кондиційне середовище відбирали на 24, 48 та 72-гу год культивування.

Результати. Висока життєздатність та інтенсивність проліферативного росту клітин спостерігались при культивуванні на поверхнях, модифікованих АПТЕСом, альбуміном, АПТЕС/декстран/альбуміном. Підвищення проліферації клітин В16F10, вирощених на нанопокриттях з альбуміном $(P<0,001)$ та АПТЕС/декстран/альбуміном $(P<0,001)$, відзначено на 48 та $72-г у$ год культивування, на відміну від контролю та інших дослідних груп. При культивуванні на покритті з АПТЕСом кількість клітин зростала, на відміну від клітин на поверхні скелець, тільки на 72-гу год культивування.

Висновки. Досліджувані наноповерхні, модифіковані альбуміном і АПТЕС/декстран/альбуміном, покращують життєздатність та проліферацію клітин лінії B16F10 та можуть бути використані як 3D-системи для вирощування клітин різних типів.

Ключові слова: культура клітин; проліферація; покриття; наноповерхні.

О.В. Штапенко, И.И. Гевкан, Ю.И. Сливчук, В.Я. Сирватка, Н.Н. Матвиєнко

\section{ФОРМИРОВАНИЕ И СВОЙСТВА ПОЛИМЕРНЫХ НАНОПОКРЫТИЙ ДЛЯ УЛУЧШЕНИЯ РОСТА КЛЕТОК IN VITRO}

Проблематика. Культивирование культур клеток на синтетических покрытиях позволяет получить комплексную пространственно организованную клеточную систему, что повышает прикрепление клеток и способствует их дальнейшей дифференциации, пролиферации и формированию междуклеточного матрикса. Поэтому возникает необходимость в изучении свойств покрытий, в частности биосовместимости с клетками, поскольку они могут быть использованы для различных биологических и медицинских исследований.

Цель. Задачей наших исследований является изучение влияния нанопокрытий, модифицированных АПТЕСом, декстраном, альбумином и их композициями, на пролиферативную и метаболическую активность клеток B16F10.

Методика реализации. В исследовании использовали клетки линии B16F10, которые культивировали на питательной среде ДМЕМ с добавлением 10 \% ФСТ, 1 \% пенициллина и стрептомицина в атмосфере с содержанием 5 \% СО 2 при $37{ }^{\circ} \mathrm{C}$ в течение 72 ч. Клетки высевали на стекла, модифицированные нанослоями в различных комбинациях: контрольная группа стекло; стекло/АПТЕС; стекло/АПТЕС/декстран; стекло/АПТЕС/альбумин; стекло/альбумин; стекло/АПТЕС/декстран/ альбумин. Влияние покрытий на пролиферативный рост и жизнеспособность культуры оценивали каждые 24 ч культивирования. Для определения активности лактатдегидрогеназы кондиционную среду отбирали на 24,48 и $72-и ̆$ час культивирования.

Результаты. Высокая жизнеспособность и интенсивность пролиферативного роста клеток наблюдались при культивировании на поверхностях, модифицированных АПТЕСом, альбумином и АПТЕС/декстран/альбумином. Повышение пролиферации клеток B16F10, выращенных на нанопокрытиях с альбумином $(P<0,001)$ и АПТЕС/декстран/альбумином $(P<0,001)$, отмечено на 48 и 72-й час культивирования, в отличие от контроля и других групп. При культивировании на покрытии с АПТЕСом количество клеток возрастало, в отличие от роста клеток на поверхности стекол, только на 72-й час культивирования.

Выводы. Исследуемые нанопокрытия, модифицированные альбумином и АПтЕС/декстран/альбумином, улучшают жизнеспособность и пролиферацию клеток линии B16F10 и могут быть использованы как 3D-системы для выращивания клеток различных типов.

Ключевые слова: культура клеток; пролиферация; покрытия; нанопокрытия. 